\title{
Ekstraksi Ciri Pelafalan Huruf Hijaiyyah Dengan Metode Mel-Frequency Cepstral Coefficients
}

\author{
YOULLIA INDRAWATY ${ }^{1}$, IRMA AMELIA DEWI ${ }^{2}$, RIZKI LUKMAN $^{3}$ \\ Institut Teknologi Nasional Bandung \\ Email : rizkilap@gmail.com
}

\begin{abstract}
ABSTRAK
Huruf hijaiyyah merupakan huruf penyusun ayat dalam Al Qur'an. Setiap huruf hijaiyyah memiliki karakteristik pelafalan yang berbeda. Tetapi dalam praktiknya, ketika membaca huruf hijaiyyah terkadang tidak memperhatikan kaidah bacaan makhorijul huruf. Makhrorijul huruf adalah cara melafalkan atau tempat keluarnya huruf hijaiyyah. Dengan adanya teknologi pengenalan suara, dalam melafalkan huruf hijaiyyah dapat dilihat perbedaannya secara kuantitatif melalui sistem. Terdapat dua tahapan agar suara dapat dikenali, dengan terlebih dahulu melakukan ekstraksi sinyal suara selanjutnya melakukan identifikasi suara atau bacaan. MFCC (Mel Frequency Cepstral Coefficients) merupakan sebuah metode untuk melakukan ektraksi ciri yang menghasilkan nilai cepstral dari sinyal suara. Penelitian ini bertujuan untuk mengetahui nilai cepstral pada setiap huruf hijaiyyah. Hasil pengujian yang telah dilakukan, setiap huruf hijaiyyah memiliki nilai cepstral yang berbeda.
\end{abstract}

Kata kunci: Huruf hijaiyyah, Speech Recognition, MFCC

\begin{abstract}
The hijaiyyah is the one verse forming in the Qur 'an. Each hijaiyyah letter has different pronunciation characteristics. But in practice, when reading Hijaiyyah letters sometimes do not pay attention to the rules of reading Makhorijul letters. Makhrorijul letters are a way to pronounce the hijaiyyah letters. Makhrorijul letter is a way to pronounce the hijaiyyah letters. With Speech Recognition technology, in pronouncing hijaiyyah letters, the difference can be seen quantitatively through the system. There are two stages of making the sound identifiable, first performing an extraction of the sound signal next doing voice identification. MFCC (Mel Frequency Cepstral Coefficients) is a method of creating a characteristic process that results in the cepstral value of the signal. The study was meant to find out the cepstral value in each of the hijaiyyah letters. The test results have already been done, each hijaiyyah letter has a different cepstral value.
\end{abstract}

Keywords: Hijaiyyah Letters, Speech Recognition, MFCC 


\section{PENDAHULUAN}

Makhorijul huruf merupakan cara melafalkan atau tempat keluarnya huruf hijaiyyah, dimana dalam membaca Al-Qur'an makhorijul huruf harus diketahui dan benar-benar dipahami dalam rangka untuk menciptakan bacaan Al-Qur'an yang baik dan benar (Ahmad, Dadan, 2013). Dengan kemajuan teknologi yang semakin pesat ucapan manusia dapat dikenali oleh komputer. Salah satu teknologi yang mendukung adalah speech recognition (pengenalan ucapan).

Speech Recognition merupakan salah satu teknik untuk mengenali suara ucapan dengan menerima masukan berupa huruf atau kata yang diucapkan sampai ucapan dikenali atau diidentifikasi sehingga dapat dimanfaatkan dalam sebuah aplikasi pengenalan ucapan (Triansyah, Ersa, 2015). Terdapat beberapa metode agar suara yang diucapkan dapat dikenali oleh komputer, salah satunya dengan menggunakan metode Mel-frequency cepstral coefficients (MFCC).

MFCC merupakan salah satu metode yang banyak digunakan dalam bidang speech technology, baik speaker recognition maupun speech recognition. Metode ini digunakan untuk melakukan feature extraction, sebuah proses yang mengkonversikan sinyal suara menjadi beberapa parameter (Manunggal, 2005). MFCC membantu untuk mengetahui nilai cepstral pada suara dihasilkan.

Tujuan dari penelitian ini yaitu membuat sistem untuk mengetahui nilai ekstraksi ciri dari setiap huruf hijaiyyah dengan menggunakan metode MFCC sebagai ekstraksi suara.

Adapun ruang lingkup penelitian yang dibuat adalah sebagai berikut:

1. Huruf hijaiyyah yang dibahas sebanyak 28 huruf dengan tanda baca fathah,

2. Pelafalan huruf hijaiyyah dilakukan oleh orang dewasa,

3. Durasi pengucapan selama 2 detik,

4. Frekuensi sampling standar $44100 \mathrm{~Hz}$,

5. Jenis suara yang digunakan mono.

\section{METODE PENELITIAN}

\subsection{Blok Diagram}

Perancangan sistem yang dibangun tersebut meliputi tahapan yang dijelaskan pada Gambar 1.

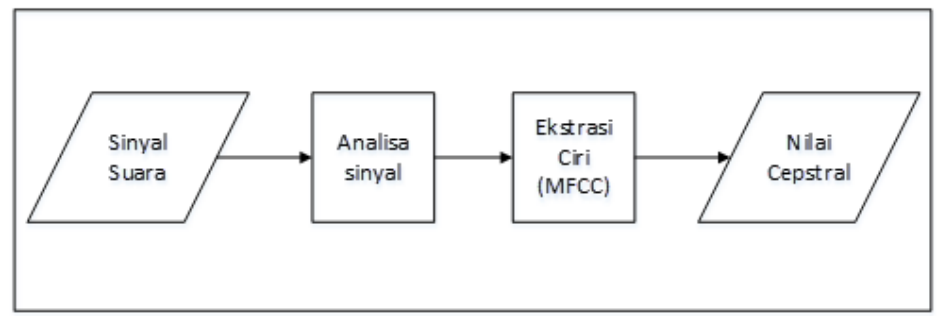

Gambar 1. Blok Diagram Sistem

Pada Gambar 1, ditunjukkan blok diagram pada sistem yang dibangun. Sinyal suara yang telah direkam akan dianalisa terlebih dahulu, selanjutnya melakukan proses ekstraksi ciri menggunakan metode MFCC dan hasil akhirnya berupa nilai cepstral. 


\subsection{Flowchart MFCC}

Untuk proses MFCC ada beberapa tahapan yang perlu dilakukan sehingga didapatkan nilai ekstraksi ciri. Pada Gambar 2 dijelaskan alur proses dari MFCC.

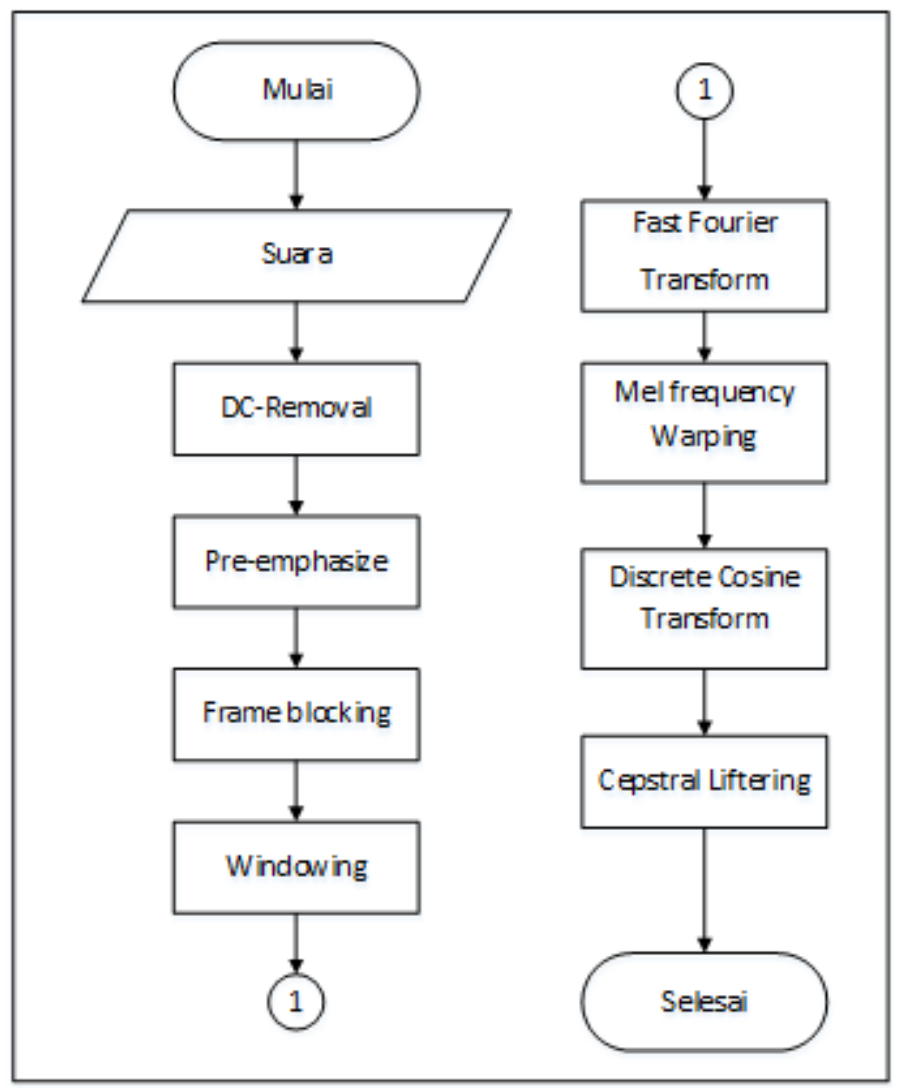

Gambar 2. Flowchart MFCC

Pada Gambar 2 merupakan tahapan-tahapan yang digunakan dalam proses feature extraction MFCC berikut penjelasannya:

1. Sinyal ucapan di rekam melalui microphone pada smartphone yang disimpan dalam format .mp3,

2. Melakukan proses DC-Removal untuk mendapatkan nilai normalisasi dari sampel sinyal.

3. Melakukan proses Pre-emphasize untuk memperbaiki sinyal dari noise (bising).

4. Melakukan proses Frame Blocking bertujuan untuk membagi sampel sinyal menjadi beberapa frame.

5. Melakukan proses Windowing untuk mengurangi efek aliasing pada ujungujung frame yang dihasilkan oleh proses frame blocking.

6. Melakukan proses FFT (Fast Fourier Transform) sehingga diperoleh sampel sinyal dalam frekuensi domain.

7. Melakukan proses Mel Frequency Warping untuk untuk mendapatkan nilai diskrit dari sinyal untuk proses DCT (Discrete Cosine Transform).

8. Melakukan proses DCT untuk mendapatkan mel cepstrums.

9. Melakukan proses Cepstral Liftering, bertujuan menghaluskan spectrum sinyal.

10. Spectrum sinyal yang telah dihasil bernilai cepstral coefficient digunakan sebagai fitur ekstraksi. 


\subsection{Penerapan Proses MFCC}

Data sinyal suara diperoleh dengan cara merekam suara melalui mikrofon yang dihubungkan dengan komputer. Perekaman suara yang dilakukan dalam aplikasi menggunakan frekuensi sampling standar $44100 \mathrm{~Hz}$. Suara dengan format . $m p 3$ ini dapat menggunakan 16 bits/sample dan 1 untuk channel mono. Durasi suara yang direkam apabila lebih pendek lebih mudah untuk diambil perbedaan fiturnya. Dalam analisis ini digunakan contoh durasi rekaman yang diambil adalah 2 detik. Penghitungan untuk menentukan data sampling:

$X=F S \times d t($ detik $) \times\left(\frac{b i t}{8}\right) \times j$

Keterangan:

$\mathrm{X}=$ Data sampling sinyal

Fs = Frekuensi sampling

bit $=$ Jumlah bit resolusi

$\mathrm{dt}=$ Durasi rekaman (detik)

$\mathrm{j}=$ Channel $(\operatorname{mono}=1)$

Perhitungan pada proses akuisi data untuk pengambilan sampling adalah:

$X=44100 \times 2 \times\left(\frac{16}{8}\right) \times 1=176400$ byte

Untuk menghitung sample rate, gunakan cara $\frac{F s}{T s}$ dengan waktu $2 \mathrm{~s}$ maka didapatkan $\frac{F s}{T s}=\frac{176400}{2}=88200 \mathrm{~Hz}$.

\section{DC-Removal}

DC-Removal bertujuan untuk menghitung rata-rata dari data sampel suara, dan mengurangkan nilai setiap sampel suara dengan nilai rata-rata tersebut. Tujuannya adalah mendapat normalisasi dari data suara input. Input dari proses ini adalah sample suara dalam bentuk array dan keluarannya adalah array sampel suara yang sudah dinormalisasi.

Untuk menghitung $D C$ Removal maka untuk sampel data sinyal sebagai berikut ( 9 , $11,13,10,15,22,14,7)$ adalah

Hitung Sampel sinyal uji:

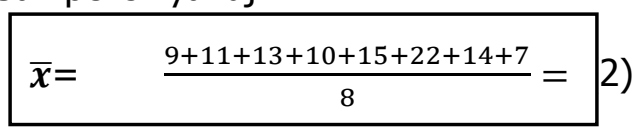

Setelah nilai rata-rata diketahui, kurangkan nilai sinyal awal dengan hasil $D C$ Removalsehingga nilai sinyal menjadi:

$$
[n]=x[n]-\overline{\mathrm{x}}, 0 \leq n \leq N-1
$$

Keterangan :

$\mathrm{y}[\mathrm{n}]=$ sampel sinyal hasil proses $D C$-Removal

$x[n]=$ sampel sinyal asli

$\overline{\mathrm{x}}=$ Nilai rata-rata sampel sinyal asli

$\mathrm{N}=$ Panjang sinyal

Proses ini menggunakan Persamaan 3 perhitungannya sebagai berikut :

$$
\begin{array}{ll}
y_{0}=9-12,6=-3,6 & y_{4}=15-12,6=2,4 \\
y_{1}=11-12,6=-1,6 & y_{5}=22-12,6=9,4 \\
y_{2}=13-12,6=0,4 & y_{6}=14-12,6=1,4 \\
y_{3}=10-12,6=-2,6 & y_{7}=7-12,6=-5,6
\end{array}
$$


Sehingga hasil data sinyal setelah dilakukan DC Removal adalah : $(-3,6,-1,6,0,4$, $-2,6,2,4,9,4,1,4,-5,6)$

\section{Pre-Emphasize}

Pre-emphasize dilakukan untuk memperbaiki sinyal dari gangguan noise, sehingga dapat meningkatkan tingkat akurasi dari proses feature extraction. Default nilai alpha yang digunakan dalam proses ini adalah 0.97 .

Dalam melakukan penghitungan pre-emphasize dengan data hasil dari DC- removal $(-3,6,-1,6,0,4,-2,6,2,4,9,4,1,4,-5,6)$ diketahui $a=0,97$.

$$
y[n]=s[n]-\alpha s[n-1], 0.9 \leq \alpha
$$

Keterangan :

$\mathrm{y}[\mathrm{n}]=$ sinyal hasil pre-emphasize filter

$\mathrm{s}[\mathrm{n}]=$ sinyal sebelum pre-emphasize

$Y_{0}=-3.6$

4,922

$Y_{1}=(-1,6-(-3,6 * 0,97))=1,892$

7,072

$Y_{2}=\left(0,4-\left(-1,6^{*} 0,97\right)\right)=1,952$

7,718

$Y_{3}=(-2,6-(0,4 * 0,97))=-2,988$

6,958

$$
\begin{aligned}
& Y_{4}=(2,4-(-2,6 * 0,97))= \\
& Y_{5}=(9,4-(2,4 * 0,97))= \\
& Y_{6}=(1,4-(9,4 * 0,97))=- \\
& Y_{7}=(-5,6-(1.4 * 0,97))=-
\end{aligned}
$$

Data sinyal baru adalah data sinyal sebelum proses pre-emphasis ditambah dengan data hasil pre-emphasis Persamaan 4. Sehingga sinyal setelah pre-emphasis :

$$
N_{n}=N_{n}+Y_{n}
$$

$\mathrm{Nn}=\mathrm{Nn}$ baru

$\mathrm{Yn}=$ signal hasil dari pre-emphasize

$\mathrm{Nn}=\mathrm{Nn}$ lama(hasil nilai pre-emphasize)

$\mathrm{N}_{0}=-3,6+(-3,6)=-7,2$

$\mathrm{N}_{1}=-1,6+(1,892)=0,292$

$\mathrm{N}_{2}=0,4+(1,952)=2,867$

$$
\begin{aligned}
& N_{4}=2,4+(4,922)=7,322 \\
& N_{5}=9,4+(7,072)=16,472 \\
& N_{6}=1,4+(-7,718)=-6,318 \\
& N_{7}=-5,6+(-6,958)=-12,558
\end{aligned}
$$$$
\mathrm{N}_{3}=-2,6+(-2,988)=2,352
$$

Begitu juga dengan data yang lainnya, sehingga didapatkan nilai sinyal setelah preemphasis adalah :

$(-7,2,0,292,2,867,2,352,7,322,16,472,-6,318,-12,558)$

\section{Frame Blocking}

Hasil perekaman suara merupakan sinyal analog yang masih bergantung terhadap waktu atau sering disebut variant time. Oleh karena itu sinyal tersebut harus dipotong-potong dalam slot-slot waktu tertentu agar bisa dianggap invariant.

Frame blocking adalah suatu proses yang bertujuan untuk membagi sampel suara menjadi beberapa frame atau slot dengan panjang tertentu. Pada penelitian yang dilakukan sinyal suara akan dipotong sepanjang $20 \mathrm{~ms}$ disetiap pergeseran sepanjang $10 \mathrm{~ms}$. 
Pada frame blocking melanjutkan perhitungan sebelumnya, pada tugas akhir ini data yang dibuat dengan waktu $=20 \mathrm{~ms}$ dan sampel rate $=88200 \mathrm{~Hz}, \quad N=88200 * 0,02$ $=1764$ Sample Point dan $M=1764 / 2=882$.

Waktu $=20 \mathrm{~ms}=0,02 \mathrm{~s}$.

$\mathrm{I}=88200 \mathrm{~Hz}$ hasil dari sample rate

$\mathrm{N}=$ sampel point

$$
\text { jumlah frame }=((I-N) / \mathrm{M}+1)
$$

Jumlah frame $=((88200-1764) / 882+1)=99$

\section{Windowing}

Ada banyak fungsi windowing namun yang digunakan dalam penelitian ini adalah hamming window karena mempunyai hasil yang lebih baik dalam pembatasan sinyal yang akan dianalisis. Proses windowing berfungsi untuk mengurangi efek diskontinuitas pada ujung-ujung frame yang dihasilkan oleh proses frame blocking. Berdasarkan Persamaan 7, maka penghitungan Hamming window dengan sampel point 1764, sebagai berikut :

$$
\begin{array}{lr}
\mathrm{W}(\mathrm{n})=0.54-0.46 * \cos \left(2 * \mathrm{pi}^{* \mathrm{j}}\right) /(\mathrm{N}-1) \\
\begin{array}{l}
W_{0}=0.54-0.46 \cos \frac{2 \times 3.14 \times 0}{1764-1}=0.08 \\
\frac{2 \times 3.14 \times 5}{1764-1}=0.08
\end{array} \\
\begin{array}{l}
W_{1}=0.54-0.46 \cos \frac{2 \times 3.14 \times 1}{1764-1}=0.08 \\
\frac{2 \times 3.14 \times 6}{1764-1}=0.08
\end{array} \\
\begin{array}{l}
W_{2}=0.54-0.46 \cos \frac{2 \times 3.14 \times 2}{1764-1}=0.08 \\
\frac{2 \times 3.14 \times 7}{1764-1}=0.08
\end{array} \\
\begin{array}{l}
W_{3}=0.54-0.46 \cos \frac{2 \times 3.14 \times 3}{1764-1}=0.08 \\
\frac{2 \times 3.14 \times 8}{1764-1}=0.08
\end{array} & W_{7}=0.54-0.54-0.46 \cos \\
&
\end{array}
$$

Selanjutnya melakukan perhitungan dengan menggunakan Persamaan 8 , sehingga didapatkan perhitungan sebagai berikut:

$$
x(n)=x i(n) * w(n), n=0.1, \ldots, N-1
$$

Keterangan :

$\mathrm{x}(\mathrm{n})=$ nilai sampel sinyal

$\mathrm{N}=$ frame size, merupakan kelipatan 2

$x i(n)=$ nilai sampel dari frame sinyal ke-1

$\mathrm{w}(\mathrm{n})=$ fungsi window

$X_{0}=-7,2 * 0.08=-0,58$

$X_{1}=-0,292 * 0.08=0,01$

$X_{2}=2,867 * 0.08=0.23$

$$
\begin{array}{rl}
X_{4}=7,322 & * 0.08=0,59 \\
X_{5} & =16,472 * 0.08=1,32 \\
X_{6} & =-6,318 * 0.08=-0,51 \\
X_{7} & =-12,558 * 0.08=-1,005
\end{array}
$$

Sehingga dan diperoleh nilai sebagai berikut : $(-0,58,0,01,0,23,0,19,0,59,1,32$ $,-0,51,-1,005)$ 


\section{Fast Fourier Transform}

Analisa berdasarkan fourier transform sama artinya dengan analisa spektrum, karena fourier transform merubah signal digital dari time domain ke frequency domain.

Berdasarkan Persamaan 9 untuk menghitung nilai FFT, Maka diperoleh perhitungan sebagai berikut:

$$
\mathrm{F}(k)=\sum_{n=0}^{N} f(n) \cos \left(\text { 2.phi.n.k. } \frac{T}{N}\right)-j \sum_{n=0}^{N} f(n) \sin \left(\text { 2.phi.n.k. } \frac{T}{N}\right)
$$

Keterangan : $\mathrm{F}(\mathrm{k})=$ Forurier Form Transform

$\mathrm{F}(\mathrm{n})=$ Sampel data

$\mathrm{N}=$ titik transform

$\mathrm{K}=$ sampel ke-n

Diketahui sinyal hasil windowing: $(-0,58,0,01,0,23,0,19,0,59,1,32,-0,51,-$ 1,005)

$$
\begin{aligned}
& \mathrm{F} 0=\frac{1}{8}\left[-5.8\left(\cos \left(\frac{2 p h i * 0 * 0}{8}\right)\right)\right]-j \sin \left(\cos \frac{2 p h i * 0 * 0}{8}\right)+ \\
& {\left[0.01\left(\cos \left(\frac{2 p h i * 0 * 1}{8}\right)\right)\right]-j \sin \left(\cos \frac{2 p h i * 0 * 1}{8}\right)+} \\
& {\left[0.23\left(\cos \left(\frac{2 p h i * 0 * 2}{8}\right)\right)\right]-j \sin \left(\cos \frac{2 p h i * 0 * 2}{8}\right)+} \\
& {\left[0.19\left(\cos \left(\frac{2 p h i * 0 * 3}{8}\right)\right)\right]-j \sin \left(\cos \frac{2 p h i * 0 * 3}{8}\right)+} \\
& {\left[0.59\left(\cos \left(\frac{2 p h i * 0 * 4}{8}\right)\right)\right]-j \sin \left(\cos \frac{2 p h i * 0 * 4}{8}\right)+} \\
& {\left[1,32\left(\cos \left(\frac{2 p h i * 0 * 5}{8}\right)\right)\right]-j \sin \left(\cos \frac{2 p h i * 0 * 5}{8}\right)+} \\
& {\left[-0,51\left(\cos \left(\frac{2 p h i * 0 * 6}{8}\right)\right)\right]-j \sin \left(\cos \frac{2 p h i * 0 * 6}{8}\right)+} \\
& {\left[-1.005\left(\cos \left(\frac{2 p h i * 0 * 7}{8}\right)\right)\right]-j \sin \left(\cos \frac{2 p h i * 0 * 7}{8}\right)+} \\
& =0,031+0 j=0.031
\end{aligned}
$$

Lakukan perhitungan yang sama sampai F7. Sehingga diperoleh data sinyal hasil FFT sebagai berikut: $(F(0)=0,031, F(1)=0.061, F(2)=0.092, F(3)=0.123, F(4)=$ $0,153, F(5)=0,184, F(6)=0,197, F(7)=0,245$

\section{Algoritma Filterbank}

Magnitude hasil dari proses FFT selanjutnya akan melalui tahap filterbank. Untuk dapat melakukan tahap filterbank ini, maka terlebih dahulu harus dicari nilai-nilai koefisien dari filterbank.

Berdasarkan Persamaan 10 untuk perhitungan filterbank, maka penghitunganya sebagai berikut:

Untuk mendapatkan $\mathrm{H}_{\mathrm{i}}$, digunakan formula :

$$
\mathrm{H}_{\mathrm{i}}=2595^{*} \log (1+1000 / 700) / \mathrm{S}_{\mathrm{i}} / 2
$$

$\mathrm{S}_{\mathrm{i}}=$ nilai hasil dari proses FFT

$2595=$ variabel hasil

mel 
Maka penghitungan sebagai berikut :

$\mathrm{H}_{0}=2595 * \log (1+1000 / 700) / 0,031 / 2=16128,80$

$\mathrm{H}_{1}=2595^{*} \log (1+1000 / 700) / 0,061 / 2=8196,60$

$\mathrm{H}_{2}=2595 * \log (1+1000 / 700) / 0,092 / 2=5434,70$

$\mathrm{H}_{3}=2595^{*} \log (1+1000 / 700) / 0,123 / / 2=4064,98$

$\mathrm{H}_{5}=2595^{*} \log (1+1000 / 700) / 0,184 / 2=2717,35$

$\mathrm{H}_{6}=2595^{*} \log (1+1000 / 700) / 0,197 / 2=2538,03$

$\mathrm{H}_{7}=2595^{*} \log (1+1000 / 700) / 0,245 / / 2=2040,79$

Maka penghitungan filterbank sebagai berikut :

$$
Y[t]=\sum_{f=1}^{n} S[j] H i[j]
$$

Keterangan :

$\mathrm{N}=$ jumlah magnitude $\operatorname{spectrum}(\mathrm{N} \epsilon \mathrm{N})$

$\mathrm{S}[\mathrm{j}]$ = Magnitude spectrum pada frekuensi $\mathrm{j}$

$\mathrm{Hi}[\mathrm{j}]=$ koefisien filterbank pada frekuensi $\mathrm{j}(1 \leq \mathrm{i} \leq \mathrm{M})$

$\mathrm{M}$ = jumlah channe/ dalam filterbank

$\mathrm{Y}_{0}=0,031 * 16128,80=499.99$

$Y_{1}=0,061 * 8196,60=499.99$

$Y_{4}=0,153 * 3267,93=499.99$

$Y_{2}=0,092 * 5434,70=499.99$

$Y_{5}=0,184 * 2717,35=499.99$

$Y_{3}=0,123 * 4064,98=499.99$

$Y_{6}=0,197 * 2538,03=499.99$

$Y_{7}=0,245 * 2040,79=499.99$

\section{Algoritma Discrete Cosine Transform (DCT)}

Proses DCT adalah langkah terakhir dari proses feature extraction. Melalui proses ini akan diperoleh beberapa nilai yang merupakan dimensi dari vector yang bersangkutan.

Berdasarkan Persamaan 12 maka untuk melakukan penghitungan DCT sebagai berikut :

Nilai hasil filterbank $=(499.99,499.99,499.99,499.99,499.99,499.99,499.99)$ Koef $(k)=8$

$$
C n=\sum_{k=1}^{k}(\log S K) \operatorname{Cos}\left[n\left(K-\frac{1}{2}\right) \frac{\pi}{k}\right]
$$

Keterangan :

$\mathrm{SK}=$ keluaran dari proses filterbank pada index $\mathrm{K}$

$\mathrm{K}=$ jumlah koefesien yang diharapkan

Untuk $\mathrm{n}=0$ maka,

$$
\begin{aligned}
& \mathrm{CO}=\log (499.99) \cos [0(0-1 / 2) 3.14 / 8]+ \\
& \log (499.99) \cos [0(1-1 / 2) 3.14 / 8]+ \\
& \log (499.99) \cos [0(2-1 / 2) 3.14 / 8]+ \\
& \log (499.99) \cos [0(3-1 / 2) 3.14 / 8]+ \\
& \log (499.99) \cos [0(4-1 / 2) 3.14 / 8]+ \\
& \log (499.99) \cos [0(5-1 / 2) 3.14 / 8]+ \\
& \log (499.99) \cos [0(6-1 / 2) 3.14 / 8]+ \\
& \log (499.99) \cos [0(7-1 / 2) 3.14 / 8] \\
& =21.592
\end{aligned}
$$

Lakukan perhitungan sama sampai C7, sehingga didapatkan nilai $(21.592$, 5.304, $0.008,4.494,2.906,2.996,0.010,1.043$ ) 


\section{Cepstral Liftering}

Hasil dari proses DCT adalah cepstrums yang sebenarnya sudah merupakan hasil akhir dari proses feature extraction. Tetapi seperti yang telah dijelaskan sebelumnya, bahwa untuk dapat meningkatkan kualitas pengenalan, maka cepstrums hasil dari proses DCT harus melewati proses cepstral liftering.

Berdasarkan Persamaan 13 maka untuk melakukan penghitungan Cepstral Liftering sebagai berikut :

$$
W[n]=\left\{\begin{array}{c}
\frac{L}{2} \sin \left(\frac{n \pi}{L}\right), \quad n=1,2, \ldots L \\
0
\end{array}\right\}
$$

Nilai Hasil DCT $=(21.592,5.304,-0.008,4.494,2.906,2.996,0.010,1.043)$

Sehingga:

$$
\begin{aligned}
\mathrm{W}_{1} & =21.592 * 8 / 2 * \sin (1 * 3.14 / 8)=0.5917 \\
& =0.3978 \\
\mathrm{~W}_{2} & =5.304 * 8 / 2 * \sin (2 * 3.14 / 8)=0.2907 \\
& =0.4924 \\
\mathrm{~W}_{3} & =-0.008 * 8 / 2 * \sin (3 * 3.14 / 8)=-0.0007 \\
& =0.0019 \\
\mathrm{~W}_{4} & =4.494 * 8 / 2 * \sin (4 * 3.14 / 8)=0.4925 \\
& =0.2285
\end{aligned}
$$

$$
\begin{aligned}
& W_{5}=2.906 * 8 / 2 * \sin (5 * 3.14 / 8) \\
& W_{6}=2.996 * 8 / 2 * \sin (6 * 3.14 / 8) \\
& W_{7}=0.010 * 8 / 2 * \sin (7 * 3.14 / 8) \\
& W_{8}=1.043 * 8 / 2 * \sin (8 * 3.14 / 8)
\end{aligned}
$$

\section{HASIL DAN PEMBAHASAN}

Pengujian dilakukan mengucapkan seluruh huruf hijaiyyah yang dilakukan oleh suara laki-laki. Dan didapatkan nilai ekstraksi ciri pada tabel berikut:

Tabel 1. Nilai Ekstraksi Ciri Huruf /a/

\begin{tabular}{|c|c|c|c|c|}
\hline \multicolumn{5}{|c|}{ Hasil Ekstraksi Ciri Dari Pelafalan Huruf /a/ } \\
\hline-49.415627 & 4.6025367 & 3.7764504 & 4.6324067 & 2.2539566 \\
\hline-19.603992 & -7.649221 & -4.322 & -2.805502 & -2.7494075 \\
\hline-0.9955674 & 4.0762067 & 3.261625 & 4.2760873 & 2.896796 \\
\hline-4.481654 & -4.3630357 & -4.3545766 & -1.9089619 & -2.9616673 \\
\hline 8.591028 & 3.5876276 & 3.3489664 & 2.3986554 & 2.2152941 \\
\hline 3.83546 & -4.242295 & -4.2981215 & -2.8023164 & -1.7102306 \\
\hline 2.0533178 & 4.738666 & 4.242403 & 3.024245 & 1.6247779 \\
\hline-2.6351454 & -4.049485 & -3.1217382 & -3.5239003 & -2.3653364 \\
\hline
\end{tabular}

Tabel 1 adalah nilai ekstraksi huruf /a/ dengan range nilai -49.415627 sampai 8.591028 .

Tabel 2. Nilai Ekstraksi Ciri Huruf / ba/

\begin{tabular}{|c|c|c|c|c|}
\hline \multicolumn{5}{|c|}{ Hasil Ekstraksi Ciri Dari Pelafalan Huruf /ba/ } \\
\hline-62.509323 & 2.193612 & 3.1608431 & 4.4871116 & 2.133211 \\
\hline-26.217062 & -5.8374753 & -4.307515 & -2.7739506 & -2.6769571 \\
\hline 7.337936 & 1.4483207 & 3.1336215 & 4.3060665 & 2.8263094 \\
\hline 9.864458 & -2.467735 & -4.185477 & -1.84825 & -2.9058812 \\
\hline 11.092244 & 3.2555027 & 3.101538 & 2.4720087 & 2.1532943 \\
\hline-4.371674 & -2.8249283 & -3.9833858 & -2.7368774 & -1.6175331 \\
\hline 8.94634 & 3.9982722 & 4.0760503 & 3.0351052 & 1.5275658 \\
\hline-4.4427786 & -3.4227393 & -3.1194801 & -3.514222 & -2.3073857 \\
\hline
\end{tabular}

Tabel 2 adalah nilai ekstraksi huruf /ba/ dengan range nilai -69.509323 sampai 11.092244 . 
Tabel 3. Nilai Ekstraksi Ciri Huruf /ta/

\begin{tabular}{|c|c|c|c|c|}
\hline \multicolumn{5}{|c|}{ Hasil Ekstraksi Ciri Dari Pelafalan Huruf /ta/ } \\
\hline-59.53147 & 5.5429 & 4.0141215 & 4.6829176 & 2.3727767 \\
\hline-18.866007 & -5.5923986 & -4.4439235 & -2.8373168 & -2.858303 \\
\hline 10.77782 & 4.968948 & 3.5382643 & 4.338176 & 3.0385022 \\
\hline 2.1707792 & -5.666702 & -4.3883576 & -1.9726893 & -3.076661 \\
\hline-0.3963981 & 4.7082267 & 3.374131 & 2.4532492 & 2.332378 \\
\hline-1.0516256 & -5.2180967 & -4.3017564 & -2.9362571 & -1.8082172 \\
\hline 4.486198 & 4.555715 & 4.2164717 & 3.1273534 & 1.7086031 \\
\hline-6.420867 & -4.1581264 & -3.1362813 & -3.6710255 & -2.4695728 \\
\hline
\end{tabular}

Tabel 3 adalah nilai ekstraksi huruf /ta/ dengan range nilai -59.53147 sampai 10.77782 .

Tabel 4. Nilai Ekstraksi Ciri Huruf /tsa/

\begin{tabular}{|c|c|c|c|c|}
\hline \multicolumn{5}{|c|}{ Hasil Ekstraksi Ciri Dari Pelafalan Huruf /tsa/ } \\
\hline-56.416035 & 2.8057928 & 3.649088 & 4.6352754 & 2.1257656 \\
\hline-15.511372 & -3.015296 & -4.240742 & -2.8302636 & -2.609881 \\
\hline 7.4626427 & 2.0365033 & 3.268242 & 4.3460555 & 2.83648 \\
\hline-4.981326 & -2.343055 & -4.0041823 & -2.0253365 & -2.91294 \\
\hline 3.5800834 & 2.055424 & 2.8880937 & 2.3861823 & 2.1792274 \\
\hline-8.124246 & -3.6164513 & -3.7848241 & -2.8147118 & -1.6480619 \\
\hline 10.1884775 & 4.088292 & 3.992194 & 2.9379878 & 1.5442922 \\
\hline-4.8062983 & -3.8581405 & -2.9705708 & -3.4354353 & -2.2941139 \\
\hline
\end{tabular}

Tabel 4 adalah nilai ekstraksi huruf /tsa/ dengan range nilai -56.416035 sampai 10.1884775 .

Tabel 5. Nilai Ekstraksi Ciri Huruf /ja/

\begin{tabular}{|c|c|c|c|c|}
\hline \multicolumn{5}{|c|}{ Hasil Ekstraksi Ciri Dari Pelafalan Huruf /ja/ } \\
\hline-50.15012 & 7.6478157 & 3.3252146 & 3.8738623 & 1.9800885 \\
\hline-18.527628 & -0.2578583 & -5.6534407 & -1.8888113 & -2.24846 \\
\hline-1.5837601 & 2.3206778 & 3.513864 & 3.9629726 & 2.3426943 \\
\hline-9.089347 & -0.4474030 & -4.8764076 & -1.9183376 & -2.3303714 \\
\hline 4.675037 & 0.23011446 & 3.0948877 & 2.570113 & 1.737176 \\
\hline-4.63631 & -1.8344779 & -3.201564 & -3.184753 & -1.304827 \\
\hline 16.55757 & 1.9456244 & 3.3254504 & 3.1474614 & 1.3952974 \\
\hline-4.7923503 & -4.4193454 & -1.5719311 & -3.5247436 & -2.3096642 \\
\hline
\end{tabular}

Tabel 5 adalah nilai ekstraksi huruf /ja/ dengan range nilai -50.15012 sampai 16.55757.

Tabel 6. Nilai Ekstraksi Ciri Huruf / ha/

\begin{tabular}{|c|c|c|c|c|}
\hline \multicolumn{5}{|c|}{ Hasil Ekstraksi Ciri Dari Pelafalan Huruf /ha/ } \\
\hline-39.74047 & 5.108149 & 3.713051 & 4.9069176 & 2.406864 \\
\hline-6.7758193 & -4.9553504 & -4.3824673 & -3.0446715 & -2.87462 \\
\hline 9.273849 & 3.6339083 & 3.5182383 & 4.498935 & 3.0397112 \\
\hline-5.242606 & -4.5011444 & -4.434601 & -2.1366563 & -3.0731292 \\
\hline 1.7902313 & 3.9884171 & 3.4978342 & 2.5800028 & 2.3304737 \\
\hline-1.0834247 & -4.5693254 & -4.4394126 & -3.0461643 & -1.8017211 \\
\hline 4.643169 & 4.07717 & 4.4405704 & 3.1990066 & 1.6908066 \\
\hline-5.1965823 & -3.7129006 & -3.3354704 & -3.708943 & -2.443406 \\
\hline
\end{tabular}

Tabel 6 adalah nilai ekstraksi huruf /ha/ dengan range nilai -39.74047 sampai 9.273849 .

Tabel 7. Nilai Ekstraksi Ciri Huruf / kho/

\begin{tabular}{|c|c|c|c|c|}
\hline \multicolumn{5}{|c|}{ Hasil Ekstraksi Ciri Dari Pelafalan Huruf /kho/ } \\
\hline-26.627468 & 3.4800131 & 2.8498673 & 4.260675 & 1.9093782 \\
\hline-23.451506 & -4.748908 & -3.5594115 & -2.4093518 & -2.4029958 \\
\hline
\end{tabular}




\begin{tabular}{|c|c|c|c|c|}
\hline 5.651264 & 3.1695044 & 2.7482507 & 3.8793237 & 2.5973516 \\
\hline-5.9179645 & -3.4506092 & -3.6817105 & -1.5499057 & -2.6602874 \\
\hline 5.9395785 & 2.76584 & 2.7269187 & 1.9954317 & 1.9433293 \\
\hline-1.1548873 & -3.583186 & -3.6726344 & -2.4807074 & -1.4396602 \\
\hline 1.9722831 & 3.320875 & 3.7496734 & 2.6556458 & 1.3606619 \\
\hline-2.7025642 & -2.9809477 & -2.681506 & -3.1920152 & -2.1268994 \\
\hline
\end{tabular}

Tabel 7 adalah nilai ekstraksi huruf /kho/ dengan range nilai -26.627468 sampai 5.9395785 .

Tabel 8. Nilai Ekstraksi Ciri Huruf /da/

\begin{tabular}{|c|c|c|c|c|}
\hline \multicolumn{5}{|c|}{ Hasil Ekstraksi Ciri Dari Pelafalan Huruf /da/ } \\
\hline-46.1354 & 3.3730395 & 3.5046775 & 4.7892947 & 2.2970936 \\
\hline-27.700619 & -4.4708714 & -4.111706 & -2.9124656 & -2.7768402 \\
\hline 6.7052026 & 3.4930863 & 3.4792569 & 4.403771 & 2.9488475 \\
\hline 1.1394407 & -3.6759226 & -4.3308363 & -2.0226142 & -2.9789886 \\
\hline 3.0844605 & 3.349221 & 3.3210762 & 2.4609396 & 2.2413464 \\
\hline 0.34790817 & -4.5330443 & -4.351767 & -2.9289575 & -1.7163968 \\
\hline 0.6762019 & 3.7165282 & 4.2827616 & 3.0765774 & 1.6236539 \\
\hline-5.0430675 & -3.6234102 & -3.2567792 & -3.6172738 & -2.3781385 \\
\hline
\end{tabular}

Tabel 8 adalah nilai ekstraksi huruf /da/ dengan range nilai -46.1354 sampai 6.7052026 .

Tabel 9. Nilai Ekstraksi Ciri Huruf /dza/

\begin{tabular}{|c|c|c|c|c|}
\hline \multicolumn{5}{|c|}{ Hasil Ekstraksi Ciri Dari Pelafalan Huruf /dza/ } \\
\hline-33.136375 & 1.9852728 & 3.0638223 & 4.477985 & 2.0515857 \\
\hline-32.32397 & -4.342399 & -3.6630282 & -2.5892947 & -2.5418801 \\
\hline 4.139538 & 3.596941 & 3.1122913 & 4.111105 & 2.7365294 \\
\hline-0.1684953 & -3.23173 & -3.8919172 & -1.7336552 & -2.7855906 \\
\hline 7.5514307 & 2.894627 & 2.9056997 & 2.1804335 & 2.0611036 \\
\hline-1.2793803 & -3.9677634 & -3.9812906 & -2.663994 & -1.5456678 \\
\hline 0.19898011 & 3.1662471 & 3.9151068 & 2.8139412 & 1.456923 \\
\hline-3.8984625 & -3.2882783 & -2.946794 & -3.3658228 & -2.2165089 \\
\hline
\end{tabular}

Tabel 9 adalah nilai ekstraksi huruf /dza/ dengan range nilai -33.136375 sampai 7.5514307.

Tabel 10. Nilai Ekstraksi Ciri Huruf /ro/

\begin{tabular}{|c|c|c|c|c|}
\hline \multicolumn{5}{|c|}{ Hasil Ekstraksi Ciri Dari Pelafalan Huruf /ro/ } \\
\hline-39.657658 & 5.1744967 & 3.1861808 & 4.838895 & 2.3530746 \\
\hline-3.1033614 & -4.0455093 & -4.568729 & -2.906254 & -2.839815 \\
\hline 13.446161 & 1.1953301 & 3.6540017 & 4.3838215 & 2.9721303 \\
\hline-18.686764 & -3.5824049 & -4.1855407 & -2.1548963 & -2.9841287 \\
\hline 1.376976 & 4.2783575 & 3.115229 & 2.5282414 & 2.2688682 \\
\hline 1.5603633 & -5.1396537 & -4.189801 & -2.9841006 & -1.7462224 \\
\hline 0.4386713 & 3.517516 & 4.511389 & 3.0421085 & 1.6524414 \\
\hline-5.3144875 & -2.7875655 & -3.351448 & -3.6163168 & -2.384108 \\
\hline
\end{tabular}

Tabel 10 adalah nilai ekstraksi huruf /ro/ dengan range nilai -39.657658 sampai 13.446161 .

Tabel 11. Nilai Ekstraksi Ciri Huruf /za/

\begin{tabular}{|c|c|c|c|c|}
\hline \multicolumn{5}{|c|}{ Hasil Ekstraksi Ciri Dari Pelafalan Huruf / za/ } \\
\hline-35.059204 & 3.7640839 & 3.7043853 & 4.370575 & 2.061718 \\
\hline-10.566767 & -4.0682592 & -4.419966 & -2.6342363 & -2.5407462 \\
\hline 0.6063767 & 1.6407088 & 3.464878 & 4.252611 & 2.7290163 \\
\hline 0.81888944 & -1.8731892 & -4.1254053 & -1.8937496 & -2.8148808 \\
\hline
\end{tabular}




\begin{tabular}{|c|c|c|c|c|}
\hline 12.643252 & 2.040342 & 2.920006 & 2.444565 & 2.0956097 \\
\hline-6.713334 & -3.1029258 & -3.799 & -2.81377 & -1.5941916 \\
\hline 9.448453 & 3.5989363 & 3.7158568 & 2.9682865 & 1.4937068 \\
\hline-6.718981 & -3.6641328 & -2.8013105 & -3.4152138 & -2.2650702 \\
\hline
\end{tabular}

Tabel 11 adalah nilai ekstraksi huruf /za/ dengan range nilai -35.059204 sampai 12.643252 .

Tabel 12. Nilai Ekstraksi Ciri Huruf /sa/

\begin{tabular}{|c|c|c|c|c|}
\hline \multicolumn{5}{|c|}{ Hasil Ekstraksi Ciri Dari Pelafalan Huruf /sa/ } \\
\hline-7.1992006 & 4.386933 & 3.6631854 & 4.9330316 & 2.4089832 \\
\hline-1.9514581 & -5.2261996 & -4.374021 & -3.044282 & -2.8773391 \\
\hline-0.3420798 & 3.8089812 & 3.5602694 & 4.4885936 & 3.05187 \\
\hline-3.1627421 & -4.4860067 & -4.481324 & -2.1690266 & -3.0897894 \\
\hline 2.468004 & 3.7212715 & 3.526557 & 2.5876474 & 2.3485465 \\
\hline-4.1309066 & -4.532647 & -4.422542 & -3.082932 & -1.8058484 \\
\hline 4.3643255 & 4.1429834 & 4.4963717 & 3.212366 & 1.6927254 \\
\hline-4.251176 & -3.7816792 & -3.3664932 & -3.729584 & -2.431373 \\
\hline
\end{tabular}

Tabel 12 adalah nilai ekstraksi huruf /sa/ dengan range nilai -7.1992006 sampai 4.9330316.

Tabel 13. Nilai Ekstraksi Ciri Huruf / sya/

\begin{tabular}{|c|c|c|c|c|}
\hline \multicolumn{5}{|c|}{ Hasil Ekstraksi Ciri Dari Pelafalan Huruf /sya/ } \\
\hline-35.006714 & 3.5301523 & 3.0914106 & 4.4894633 & 2.0807319 \\
\hline-27.410875 & -4.630751 & -3.8719149 & -2.6208246 & -2.5608177 \\
\hline-1.9674258 & 3.195917 & 3.0318706 & 4.0726123 & 2.7544012 \\
\hline-3.135424 & -3.8458726 & -3.9818065 & -1.7843412 & -2.8066523 \\
\hline 2.2899249 & 3.147408 & 3.033359 & 2.1775677 & 2.0789015 \\
\hline-2.0743253 & -3.9172037 & -3.907779 & -2.6940718 & -1.5558351 \\
\hline 3.4952805 & 3.6217625 & 4.0491986 & 2.843225 & 1.4770422 \\
\hline-3.3408148 & -3.257935 & -2.891919 & -3.3803096 & -2.2314336 \\
\hline
\end{tabular}

Tabel 13 adalah nilai ekstraksi huruf /sya/ dengan range nilai -35.006714 sampai 4.4894633.

Tabel 14. Nilai Ekstraksi Ciri Huruf /so/

\begin{tabular}{|c|c|c|c|c|}
\hline \multicolumn{5}{|c|}{ Hasil Ekstraksi Ciri Dari Pelafalan Huruf /so/ } \\
\hline-10.482418 & 3.0146086 & 4.0382733 & 5.4440994 & 2.7631826 \\
\hline-9.10919 & -4.537568 & -4.8375616 & -3.5407872 & -3.2116542 \\
\hline-5.9737444 & 3.4620564 & 4.0477467 & 4.962955 & 3.3703475 \\
\hline-1.3315679 & -4.3712707 & -4.991743 & -2.6358519 & -3.3908157 \\
\hline 2.5565019 & 3.7771308 & 4.0425014 & 3.0220113 & 2.6278563 \\
\hline-2.5800295 & -4.702185 & -4.9321876 & -3.502905 & -2.0599837 \\
\hline 2.4471078 & 4.4106154 & 5.0337086 & 3.610555 & 1.9271944 \\
\hline-2.6145844 & -4.1243987 & -3.885724 & -4.1060367 & -2.639049 \\
\hline
\end{tabular}

Tabel 14 adalah nilai ekstraksi huruf /so/ dengan range nilai -10.482418 sampai 5.4440994 .

Tabel 15. Nilai Ekstraksi Ciri Huruf /do/

\begin{tabular}{|c|c|c|c|c|}
\hline \multicolumn{5}{|c|}{ Hasil Ekstraksi Ciri Dari Pelafalan Huruf /do/ } \\
\hline-43.72503 & 4.5033746 & 3.5503967 & 4.851586 & 2.3492348 \\
\hline-10.821611 & -4.6808543 & -4.286312 & -2.9835236 & -2.8221195 \\
\hline 4.074492 & 2.660217 & 3.5068858 & 4.461488 & 3.0108516 \\
\hline-0.23097335 & -3.805301 & -4.3836894 & -2.1453629 & -3.05162 \\
\hline 4.0434422 & 2.969014 & 3.3704457 & 2.547627 & 2.3049333 \\
\hline-10.02586 & -4.1174173 & -4.313581 & -3.0397837 & -1.7570732 \\
\hline 5.78534 & 3.9253616 & 4.4000025 & 3.167566 & 1.656682 \\
\hline-4.6424627 & -3.730318 & -3.3060718 & -3.693203 & -2.3946092 \\
\hline
\end{tabular}


Tabel 15 adalah nilai ekstraksi huruf /do/ dengan range nilai -43.72503 sampai 5.78534 .

Tabel 16. Nilai Ekstraksi Ciri Huruf /to/

\begin{tabular}{|c|c|c|c|c|}
\hline \multicolumn{5}{|c|}{ Hasil Ekstraksi Ciri Dari Pelafalan Huruf /to/ } \\
\hline-81.09579 & 3.7012668 & 3.160786 & 5.290876 & 2.5941243 \\
\hline-10.640301 & -3.114129 & -5.087764 & -3.4002347 & -3.03662 \\
\hline 0.66204685 & 6.552692 & 3.7890062 & 4.8844194 & 3.2684634 \\
\hline-24.804832 & -4.944902 & -5.2044973 & -2.4353096 & -3.2464194 \\
\hline 13.890984 & 5.245047 & 3.635835 & 2.751787 & 2.4760227 \\
\hline-3.4652426 & -4.072068 & -4.435308 & -3.1689477 & -1.8952116 \\
\hline 2.3415768 & 3.473036 & 4.4845533 & 3.3055203 & 1.711819 \\
\hline 3.6867745 & -3.2861197 & -3.353243 & -3.7926066 & -2.5338464 \\
\hline
\end{tabular}

Tabel 16 adalah nilai ekstraksi huruf/to/ dengan range nilai -81.09579 sampai 13.890984 .

Tabel 17. Nilai Ekstraksi Ciri Huruf /dzo/

\begin{tabular}{|c|c|c|c|c|}
\hline \multicolumn{5}{|c|}{ Hasil Ekstraksi Ciri Dari Pelafalan Huruf /dzo/ } \\
\hline-15.040157 & 4.0538683 & 3.8775752 & 5.0706396 & 2.490223 \\
\hline-7.5780725 & -5.5822263 & -4.5154595 & -3.182006 & -2.9517925 \\
\hline 3.3385239 & 4.044462 & 3.648406 & 4.6230774 & 3.11349 \\
\hline-5.867426 & -4.0916176 & -4.578478 & -2.2636344 & -3.1469252 \\
\hline 5.4459476 & 3.356355 & 3.6336575 & 2.7031047 & 2.4010947 \\
\hline 0.14545675 & -4.2611985 & -4.5870814 & -3.1557422 & -1.8675542 \\
\hline 0.8471878 & 4.208706 & 4.6249385 & 3.3021488 & 1.7470856 \\
\hline-1.8712077 & -3.964446 & -3.5261729 & -3.7979963 & -2.4831936 \\
\hline
\end{tabular}

Tabel 17 adalah nilai ekstraksi huruf /dzo/ dengan range nilai -15.040157 sampai 5.4459476 .

Tabel 18. Nilai Ekstraksi Ciri Huruf /aa/

\begin{tabular}{|c|c|c|c|c|}
\hline \multicolumn{5}{|c|}{ Hasil Ekstraksi Ciri Dari Pelafalan Huruf /aa/ } \\
\hline-26.677866 & 3.5943143 & 3.355213 & 4.8385315 & 2.2885115 \\
\hline-18.803679 & -5.718583 & -4.192401 & -2.923985 & -2.7791955 \\
\hline-6.0745325 & 2.9148428 & 3.320043 & 4.336659 & 2.9417784 \\
\hline-12.059564 & -3.946694 & -4.279656 & -2.077433 & -2.9770484 \\
\hline-0.72754383 & 2.9929338 & 3.4362116 & 2.3992844 & 2.2537632 \\
\hline-1.8782656 & -4.2969537 & -4.1701427 & -2.9859989 & -1.7091581 \\
\hline-0.14222068 & 3.8747559 & 4.414875 & 3.0471857 & 1.6317058 \\
\hline-3.6600578 & -3.6569703 & -3.1273487 & -3.6243007 & -2.3521373 \\
\hline
\end{tabular}

Tabel 18 adalah nilai ekstraksi huruf /aa/ dengan range nilai -26.677866 sampai 4.8385315 .

Tabel 19. Nilai Ekstraksi Ciri Huruf /gho/

\begin{tabular}{|c|c|c|c|c|}
\hline \multicolumn{5}{|c|}{ Hasil Ekstraksi Ciri Dari Pelafalan Huruf /gho/ } \\
\hline-46.729195 & 4.93161 & 3.522058 & 4.8696146 & 2.3515942 \\
\hline-3.8272717 & -5.7200265 & -4.272323 & -2.9851546 & -2.8290024 \\
\hline 0.87228733 & 3.772537 & 3.4119444 & 4.4109235 & 3.0063803 \\
\hline-10.291633 & -4.5158496 & -4.341767 & -2.1187882 & -3.048428 \\
\hline 5.476539 & 3.6256192 & 3.420056 & 2.5140357 & 2.3177023 \\
\hline-6.6154437 & -4.4769416 & -4.289908 & -3.0408354 & -1.770819 \\
\hline 5.4645 & 3.9984422 & 4.413683 & 3.1450768 & 1.6626858 \\
\hline-5.5211186 & -3.6806524 & -3.2598193 & -3.6743646 & -2.3943484 \\
\hline
\end{tabular}

Tabel 19 adalah nilai ekstraksi huruf /gho/ dengan range nilai -46.729195 sampai 4.93161. 
Tabel 20. Nilai Ekstraksi Ciri Huruf /fa/

\begin{tabular}{|c|c|c|c|c|}
\hline \multicolumn{5}{|c|}{ Hasil Ekstraksi Ciri Dari Pelafalan Huruf /fa/ } \\
\hline-77.48307 & 4.695721 & 3.9720724 & 5.2901297 & 2.6337593 \\
\hline-11.462761 & -5.7091856 & -4.7682405 & -3.4032538 & -3.1007848 \\
\hline 7.7362666 & 3.5553427 & 3.882609 & 4.7960234 & 3.2510853 \\
\hline-14.04736 & -4.6692553 & -4.809923 & -2.4786947 & -3.2674685 \\
\hline 2.2872548 & 3.9925058 & 3.8873744 & 2.832341 & 2.5254545 \\
\hline-2.409936 & -5.0159755 & -4.727814 & -3.3514662 & -1.9705045 \\
\hline 2.2584677 & 4.4425406 & 4.837786 & 3.430913 & 1.8614566 \\
\hline-4.6261406 & -4.135632 & -3.6625807 & -3.963476 & -2.576269 \\
\hline
\end{tabular}

Tabel 20 adalah nilai ekstraksi huruf /fa/ dengan range nilai -77.48307 sampai 7.7362666 .

Tabel 21. Nilai Ekstraksi Ciri Huruf /qo/

\begin{tabular}{|c|c|c|c|c|}
\hline \multicolumn{5}{|c|}{ Hasil Ekstraksi Ciri Dari Pelafalan Huruf /qo/ } \\
\hline-52.897568 & 6.0711246 & 3.4873238 & 4.7937875 & 2.2945228 \\
\hline-18.099157 & -5.0468445 & -4.292909 & -2.8888898 & -2.7547956 \\
\hline-0.88296294 & 4.008487 & 3.3755457 & 4.30479 & 2.9413245 \\
\hline-10.950895 & -3.801609 & -4.351102 & -2.0215945 & -2.9704278 \\
\hline 1.798612 & 4.0201187 & 3.3914783 & 2.3879743 & 2.2419913 \\
\hline 0.1343854 & -4.464371 & -4.178852 & -2.9311714 & -1.7209477 \\
\hline 3.4504924 & 4.305233 & 4.350169 & 3.0498803 & 1.613225 \\
\hline-3.450433 & -3.6477628 & -3.1092303 & -3.577453 & -2.3871884 \\
\hline
\end{tabular}

Tabel 21 adalah nilai ekstraksi huruf /qo/ dengan range nilai -52.897568 sampai 6.0711246 .

Tabel 22. Nilai Ekstraksi Ciri Huruf / ka/

\begin{tabular}{|c|c|c|c|c|}
\hline \multicolumn{5}{|c|}{ Hasil Ekstraksi Ciri Dari Pelafalan Huruf /ka/ } \\
\hline-34.005733 & 4.1087766 & 3.6867094 & 5.0440617 & 2.561691 \\
\hline 10.080491 & -5.6075835 & -4.441074 & -3.1791058 & -3.0370011 \\
\hline-4.5703053 & 5.1755223 & 3.7350354 & 4.660013 & 3.229015 \\
\hline-5.546599 & -6.1218085 & -4.713792 & -2.3498464 & -3.2808862 \\
\hline 10.19755 & 5.348935 & 3.7335274 & 2.8162987 & 2.5267072 \\
\hline-7.455867 & -5.5970426 & -4.6117864 & -3.285794 & -1.9562631 \\
\hline 5.7458544 & 4.6765985 & 4.6073513 & 3.4095304 & 1.800772 \\
\hline-3.8109903 & -3.899619 & -3.487286 & -3.885633 & -2.528681 \\
\hline
\end{tabular}

Tabel 22 adalah nilai ekstraksi huruf /ka/ dengan range nilai -34.005733 sampai 10.19755 .

Tabel 23. Nilai Ekstraksi Ciri Huruf /la/

\begin{tabular}{|c|c|c|c|c|}
\hline \multicolumn{5}{|c|}{ Hasil Ekstraksi Ciri Dari Pelafalan Huruf /la/ } \\
\hline-25.765894 & 2.500775 & 3.3474426 & 4.6681333 & 2.1798153 \\
\hline-20.042458 & -4.9121614 & -4.0915837 & -2.7912478 & -2.6638703 \\
\hline 0.7905726 & 3.7837918 & 3.2997584 & 4.2474294 & 2.8493283 \\
\hline-3.3665414 & -4.036216 & -4.1494493 & -1.8921472 & -2.9035747 \\
\hline 7.368304 & 3.2396865 & 3.1538398 & 2.33937 & 2.1747875 \\
\hline-1.600228 & -3.9771917 & -4.1164045 & -2.8141243 & -1.6471488 \\
\hline 0.9185694 & 3.5799189 & 4.1660104 & 2.9698849 & 1.5443517 \\
\hline-2.352452 & -3.430263 & -3.1317978 & -3.494198 & -2.2881327 \\
\hline
\end{tabular}

Tabel 23 adalah nilai ekstraksi huruf /la/ dengan range nilai -25.765894 sampai 7.368304 .

Tabel 24. Nilai Ekstraksi Ciri Huruf / ma/

Hasil Ekstraksi Ciri Dari Pelafalan Huruf / $\mathrm{ma} /$

\begin{tabular}{|l|l|l|l|l|}
\hline-42.947968 & 6.662135 & 4.0276294 & 5.1427064 & 2.4859867 \\
\hline
\end{tabular}




\begin{tabular}{|c|c|c|c|c|}
\hline-25.0638 & -5.0399795 & -5.1633096 & -3.1736786 & -2.8734422 \\
\hline-9.495469 & 4.7757063 & 3.928692 & 4.5351534 & 3.1160684 \\
\hline-6.65152 & -4.9503922 & -4.913969 & -2.2838748 & -3.0956895 \\
\hline 4.7843347 & 3.7708857 & 3.9846952 & 2.5826447 & 2.4070094 \\
\hline 4.3053336 & -5.504553 & -4.595009 & -3.1178048 & -1.8397994 \\
\hline 5.0454288 & 4.48388 & 4.8887963 & 3.2495236 & 1.7594028 \\
\hline 0.6221033 & -4.8979197 & -3.4462538 & -3.7159212 & -2.5012643 \\
\hline
\end{tabular}

Tabel 24 adalah nilai ekstraksi huruf $/ \mathrm{ma}$ / dengan range nilai -42.947968 sampai 6.662135 .

Tabel 25. Nilai Ekstraksi Ciri Huruf /na/

\begin{tabular}{|c|c|c|c|c|}
\hline \multicolumn{5}{|c|}{ Hasil Ekstraksi Ciri Dari Pelafalan Huruf /na/ } \\
\hline-54.50509 & 5.1266007 & 5.1115084 & 5.3769374 & 2.619774 \\
\hline-8.512604 & -5.12089 & -5.5995893 & -3.4579387 & -3.0848818 \\
\hline 3.939629 & 5.735378 & 4.559402 & 4.872985 & 3.2678583 \\
\hline 4.456211 & -6.1414304 & -5.4865026 & -2.4345448 & -3.2999616 \\
\hline 4.899439 & 4.238459 & 4.3185425 & 2.878194 & 2.5572789 \\
\hline-3.7579143 & -6.010221 & -5.129771 & -3.3181298 & -2.0222745 \\
\hline-1.6423761 & 5.5173793 & 5.1228337 & 3.435358 & 1.899147 \\
\hline-3.5385811 & -4.8300705 & -3.982036 & -3.9625456 & -2.6344283 \\
\hline
\end{tabular}

Tabel 25 adalah nilai ekstraksi huruf /na/ dengan range nilai -54.50509 sampai 5.735378 .

Tabel 26. Nilai Ekstraksi Ciri Huruf / wa/

\begin{tabular}{|c|c|c|c|c|}
\hline \multicolumn{5}{|c|}{ Hasil Ekstraksi Ciri Dari Pelafalan Huruf /wa/ } \\
\hline-7.5230465 & 3.9800742 & 3.2492485 & 4.733762 & 2.23958 \\
\hline-6.6112576 & -4.6449337 & -4.0497017 & -2.8678238 & -2.7218122 \\
\hline 6.8651447 & 2.598518 & 3.2336879 & 4.2907934 & 2.8914046 \\
\hline-9.817951 & -3.6116173 & -4.1821265 & -1.975398 & -2.9266598 \\
\hline 0.4424329 & 3.1211512 & 3.2633305 & 2.371288 & 2.201205 \\
\hline-0.43534157 & -4.185781 & -4.1445456 & -2.8897328 & -1.6716094 \\
\hline 1.2579585 & 3.693083 & 4.2384143 & 3.0044155 & 1.5804247 \\
\hline-3.5529535 & -3.354374 & -3.1094456 & -3.5456886 & -2.3247416 \\
\hline
\end{tabular}

Tabel 26 adalah nilai ekstraksi huruf /wa/ dengan range nilai -9.817951 sampai 6.8651447.

Tabel 27. Nilai Ekstraksi Ciri Huruf / Ha/

\begin{tabular}{|c|c|c|c|c|}
\hline \multicolumn{5}{|c|}{ Hasil Ekstraksi Ciri Dari Pelafalan Huruf / Ha/ } \\
\hline-9.688971 & 3.7163603 & 2.9303992 & 4.377832 & 1.9990404 \\
\hline-15.607821 & -4.6688075 & -3.685626 & -2.512572 & -2.4899755 \\
\hline 0.3172532 & 3.0758662 & 2.8826008 & 3.9764955 & 2.6894557 \\
\hline-3.7609932 & -3.8065627 & -3.8216414 & -1.686958 & -2.7488518 \\
\hline 3.8449879 & 2.92584409 & 2.8768418 & 2.0992234 & 2.027544 \\
\hline-5.577623 & -3.8312182 & -3.7881417 & -2.6208034 & -1.5026953 \\
\hline 4.3585396 & 3.4231644 & 3.9113538 & 2.7629702 & 1.4208355 \\
\hline-4.182124 & -3.0967214 & -2.7929606 & -3.307912 & -2.1757257 \\
\hline
\end{tabular}

Tabel 27 adalah nilai ekstraksi huruf $/ \mathrm{Ha} /$ dengan range nilai -15.607821 sampai 4.377832 .

Tabel 28. Nilai Ekstraksi Ciri Huruf /ya/

Hasil Ekstraksi Ciri Dari Pelafalan Huruf /ya/

\begin{tabular}{|c|c|c|c|c|}
\hline \multicolumn{5}{|c|}{ Hasil Ekstraksi Ciri Dari Pelafalan Huruf /ya/ } \\
\hline-53.669964 & 3.738049 & 3.5815165 & 4.852318 & 2.273525 \\
\hline-26.015846 & -4.713441 & -4.211227 & -2.882102 & -2.7715244 \\
\hline-0.86498517 & 2.7413628 & 3.4360702 & 4.352932 & 2.9258716 \\
\hline-11.92991 & -4.26525 & -4.1626043 & -2.0482872 & -2.9707522 \\
\hline-4.3762503 & 3.7188253 & 3.5097144 & 2.3841534 & 2.2324247 \\
\hline
\end{tabular}




\begin{tabular}{|c|c|c|c|c|}
\hline-1.6735393 & -4.2968874 & -4.1247087 & -2.9592438 & -1.7040567 \\
\hline 1.9224265 & 3.8664818 & 4.4774966 & 3.0293908 & 1.6165894 \\
\hline-5.4060864 & -3.4641306 & -3.0505357 & -3.6111124 & -2.3633518 \\
\hline
\end{tabular}

Tabel 28 adalah nilai ekstraksi huruf /ya/ dengan range nilai -53.669964 sampai 4.852318 .

\section{KESIMPULAN}

Dari hasil pengujian dengan menggunakan metode Mel-Frequency Cepstral Coefficients sistem dapat merubah sinyal suara menjadi nilai cepstral. Dari semua huruf hijaiyyah (a sampai ya) yang diucapkan memiliki nilai ekstraksi ciri yang berbeda.

\section{DAFTAR PUSTAKA}

Hafiz, Adrian., dkk., 2016. Aplikasi Pendeteksian Emosi Manusia Menggunakan Metode MFCC dan DTW. Prosiding SNTI Fakultas Teknologi Informasi Universitas Tarumanagara Jakarta, hal 29.

Triansyah, Ersa., dkk., 2017. Implementas Metode Pattern Recognition Untuk Pengenalan Ucapan Huruf Hijaiyyah.

Ahmad, Dadan., 2013. Makhroj dan Sifat-Sifat Huruf Hijaiyyah Dalam Al-Qur'an (online), (http://dadanar.blogspot.com/2013/11/makhroj-dan-sifat-sifat-hurufhijaiyyah.html, diakses 2 Oktober 2017).

Solinin, Akhmad., 2014. Mengenal dan Memahami Arti Huruf Hijaiyah (online), (https://visiuniversal.blogspot.com/2014/07/mengenal-dan-memahami-artihuruf.html diakses 3 September 2018)

Manunggal, HS. 2005. Perancangan dan Pembuatan Perangkat Lunak Pengenalan Suara Pembicara dengan Menggunakan Analisa MFCC Feature Extraction. Surabaya.

Ade Saputro, Bagus., dkk., 2018. Sistem Pembelajaran Bacaan Iqra Melalui Voice Recognition Menggunakan Metode MFCC Dan VQ.

Rabiner, Lawrence., Juang, Biing-Huang., 1993. Fundamentals Of Speech Recognition. Prentice Hall International Editions. 